\title{
Pemanfaatan Lingkungan Sekolah Sebagai Sumber Belajar Bagi Siswa Di Slbn Pembina Provinsi Kalimantan Timur Semester Genap Tahun Pembelajaran 2019/2020
}

\author{
Afdal $^{1^{*}}$, Andi Alif Tunru ${ }^{2}$, Disman Ubang ${ }^{3}$ \\ ${ }^{1,2,3}$ Universitas Widya Gama Mahakam Samarinda, Indonesia \\ 1*afdalpalalloi@gmain.com
}

\begin{abstract}
Abstrak
Proses pembelajaran di SLB saat ini cukup baik dan menarik, hal ini karena semakin baiknya lulusan PLB dari perguruan tinggi yang mencetak guru untuk sekolah Anak Berkebutuhan Khusus (ABK). Pembelajaran di SLB semakin hari semakin diperhatikan oleh pemerintah, salah satu contoh adalah di SLBN Pembina Provinsi Kalimantan Timur. Gubernur saat ini semakin memperhatikan anak ABK, pembangunan gedung sekolah yang terus direnovasi, kelengkapan media pembelajaran dan buku ajar, dan honor guru kontrak yang terus dinaikkan. Hal ini sangat membantu terciptanya pembelajaran yang baik dan efektif di SLBN Pembina Provinsi Kalimantan Timur. Tujuan pengabdian ini adalah untuk membantu anak ABK mengenal lingkungan sekitarnya dengan memanfaatkan lingkungan sekolah. Dalam hal ini, yang masih perlu diperhatikan untuk sekolah ABK adalah perlunya kreatifitas guru yang lebih ekstra, karena setiap tahunnya anak ABK semakin banyak mengalami peningkatan pendaftar sehingga jumlah siswa dalam satu kelas adalah berjumlah lima sampai enam orang yang mestinya hanya empat siswa saja. Selain itu jumlah siswa ABK khususnya tuna grahita semakin meningkat sehingga dengan tingkat intelegensi yang rendah itu harus membuat guru jadi sabar dalam menghadapinya. Setiap karakter siswa ABK pasti berbeda, dengan perbedaan itulah yang kadang membuat guru sangat sulit untuk mengajari mereka. Salah satu usaha untuk memancing dan membuat siswa bergairah belajar adalah dengan cara memanfaatkan lingkungan sekolah sebagai sumber belajar untuk anak ABK, sehingga mereka terlihat senang dan mau belajar. SLBN Pembina merupakan SLB percontohan di Kalimantan Timur, kondisi fisik sekolahnya cukup baik, nyaman, dan lengkap untuk dijadikan sebagai sumber belajar sehingga mampu merangsang otak anak bisa berfikir dan kreatif.
\end{abstract}

Kata kunci: Pemanfaatan lingkungan sekolah, sumber belajar.

\section{PENDAHULUAN}

Pada dasarnya semua jenis lingkungan yang ada di sekitar kita dapat dimanfaatkan untuk mengoptimalkan kegiatan pendidikan siswa sepanjang relevan dengan komptensi dasar dan hasil belajar yang bisa berupa lingkungan alam atau lingkungan fisik, lingkungan sosial dan lingkungan budaya atau buatan. Lingkungan alam atau lingkungan fisik adalah segala sesuatu yang sifatnya alamiah, seperti sumber daya alam yaitu air, hutan, tanah, batu-batuan, tumbuh-tumbuhan dan hewan yang merupakan flora dan fauna, sungai, iklim, suhu, dan sebagainya. Lingkungan alam sifatnya relatif menetap, oleh karena itu jenis lingkungan ini akan lebih mudah dikenal dan dipelajari oleh siswa. Sesuai dengan kemampuannya, siswa dapat mengamati perubahan yang terjadi dan dialami dalam kehidupan sehari-hari, termasuk juga proses terjadinya. Dengan mempelajari lingkungan alam ini diharapkan siswa akan lebih memahami gejala alam yang terjadi dalam kehidupannya sehari-hari, lebih dari itu diharapkan juga dapat menumbuhkan kesadaran sejak awal untuk mencintai alam, dan mungkin juga anak bisa turut berpartisipasi untuk menjaga dan memelihara lingkungan alam.

Lingkungan pendidikan adalah berbagai faktor yang berpengaruh terhadap pendidikan atau berbagai lingkungan tempat berlangsungan proses pendidikan. Jadi lingkungan sekolah adalah kesatuan ruang dalam lembaga pendidikan formal yang memberikan pengaruh pembentukan sikap dan pengembangan potensi siswa. Namun bagaimanakah cara 
memanfaatkaan lingkungan sebagai sumber belajar? Tentu perlu mempertimbangkan berbagai faktor dalam pembelajaran tidak hanya aspek pengajarannya, karena kalau pengaajaran hanya terbatas pada interaksi guru dan siswa. Sedang pembelajaran melibatkan semua komponen pembelajaran yaitu: guru, siswa, media, materi, evaluasi, waktu, kelas/ruang, metode pembelajaran. Media harus menjadi komponen efektif agar dapat mendukung pembelajaran efektif. Melalui media yang efektif, pembelajaran efektif, maka siswa akan belajar dengan nyaman sehingga prestasi dan hasil belajar menjadi lebih baik.

Tujuan penelitian ini adalah untuk menjadikan lingkungan sekolah sebagai sumber belajar bagi siswa SLBN Pembina Kalimantan Timur. Target dan luaran dalam kegiatan ini adalah siswa SLBN Pembina Kalimantan Timur yang masuk pada kategori tunagrahita yaitu memperlihatkan benda benda di sekitarnya sebagai teman sehari hari, mampu memanfaatkan benda benda di sekitarnya dalam kehidupan sehari hari, dan siswa akan merasa kangen dengan sekolahnya karena teringat dengan kegiatan yang dilakukan di lingkungan sekolah.

Semakin baik sistem belajar yang dikembangkan maka semakin meningkat pengetahuan dan keterampilannya. Untuk itu, belajar harus dikonsep dengan baik untuk mendapatkan hasil yang maksimal. Menurut Djaali (2012:115), belajar adalah aktivitas untuk mendapatkan pengetahuan akademik. Belajar juga digambarkan sebagai perubahan tingkah laku yang relatif tetap dan terjadi sebagai hasil latihan atau pengalaman. Walgito (2004:167) menyatakan bahwa belajar suatu proses, yang mengakibatkan adanya perubahan perilaku (change in behavior or performance).

Hamalik (2006:154) menjelaskan bahwa belajar adalah perubahan tingkah laku yang relatif mantap berkat latihan dan pengalaman. Belajar sesungguhnya adalah ciri khas manusia yang membedakannya dengan binatang. Belajar yang dilakukan oleh manusia merupakan bagian dari hidupnya, berlangsung seumur hidup, kapan saja dan dimana saja, serta dijalankan dalam waktu yang tidak dapat ditentukan sebelumnya. Belajar yang dilakukan oleh manusia senantiasa dilandasi itikad dan maksud tertentu. Menurut Syah (2010:93), Belajar adalah key term (istilah kunci) yang paling vital dalam setiap suasan pendidikan, sehingga tanpa belajar sesuungguhnya tidak pernah ada pendidikan.

Hal ini menunjukkan bahwa sebagai suatu prises, belajar hampir selau mendapat tempat yang luas dalam berbagai disiplin ilmu yang berkaitan dengan upaya kependidikan, misalnya psikologi pendidikan. Perubahan dan kemampuan untuk berubah merupakan batasan dan makna yang terkandung dalam belajar. Menurut Purwanto (2013:84-85), beberapa elemen yang penting yang mencirikan pengertian tentang belajar, yaitu Belajar merupakan suatu perubahan dalam tingkah laku dimana perubahan itu dapat mengarah kepada tingkah laku yang lebih baik, belajar merupakan suatu perubahan yang terjadi melalui latihan danpengalaman, untuk dapat disebut belajar, maka perubahan itu harus relatif mantap, tingkah laku yang mengalami perubahan karena belajar menyangkut beberapa aspek kepribadian, baik fisik maupun psikis, seperti perubahan dalam pengertian, pemecahan suatu masalah atau berpikir, keterampilan, kecakapan, kebiasanataupun sikap.

Dapat diinterpretasikan bahwa belajar merupakan perubahan yang terjadi dalam diri seseorang setelah melakukan kegiatan pembelajaran yang diwujukan melalui perubahan tingkah laku yang lebih baik.

Lingkungan belajar menurut Saroni (2006:82-84), adalah Segala sesuatu yang berhubungan dengan tempat proses pembelajaran dilaksanakan. Lingkungan ini mencakup dua hal utama, yaitu lingkungan fisik dan lingkungan sosial, kedua aspek lingkungan tersebut dalam proses pembelajaran haruslah saling mendukung, sehingga siswa merasa krasan di sekolah dan mau mengikuti proses pembelajaran. 
Salah satu aspek penting keberhasilan dalam proses pembelajaran yang dilakukan oleh guru menurut Saroni (2006:81-82), adalah Penciptaan kondisi pembelajaran yang efektif. Kondisi pembelajaran efektif adalah kondisi yang benar-benar kondusif, kondisi yang benarbenar sesuai dan mendukung kelancaran serta kelangsungan proses pembelajan.

Berdasarkan uraian tentang lingkungan belajar tersebut di atas maka dapat disarikan bahwa lingkungan belajar yang di kelola adalah terutama bagaimana mengemas suasana kelas, kelas belajarnya, dan sumber-sumberbelajar yang ada di sekolah ataupun yang dapat diadakan dari dibuat atau alam lingkungan sekolah. Lingkungan belajar dalam hal terutama di kelas adalah sesuatu yang diupayakan atau diciptakan oleh guru agar proses pembelajaran kondusif dapat mencapai tujuan pembelajaran.

Dalam hal ini tugas guru menurut Mulyasa (2006:210\&218), adalah memberikan kemudahan belajar, dengan memanfaatkan lingkungan belajar yang ada di sekolah seoptimal mungkin, menyampaikan materi pembelajaran yang berupa hafalan, dan menciptakan dan mengatur lingkungan belajar terutama di kelas dan strategi pembelajaran yang memungkinkan siswa belajar. Oleh karena itu peran guru harus bisa mengoptimalkan pemanfaatan lingkungan fisik di kelas yang diharapkan suasana lingkungan sosial kelas menjadikan proses pembelajaran menjadi bermakna. Dengan terciptanya tanggung jawab bersama antara siswa dan guru maka kebersaman akan terbentuk sehingga pemanfaatan lingkungan belajar dapat meningkatkan pembelajaran dan motivasi belajar.

\section{METODE PELAKSANAAN}

\section{Waktu dan Tempat}

Kegiatan pengabdian masyarakat ini dilaksanakan di taman lingkungan sekolah SLBN Pembina Kalimantan Timur pada akhir bulan Januari sampai bulan Februari 2020 setiap saat dikala siswanya lagi memungkinkan untuk belajar.

\section{Alat dan Bahan}

Alat dan bahan yang digunakan dalam kegiatan ini adalah lingkungan sekolah.

\section{Rancangan Pengabdian Kepada Masyarakat} bermain.

Metode yang diterapkan dalam kegiatan ini adalah ceramah, tanya jawab dan sambil

\section{Langkah-langkah Kegiatan}

Adapun langkah yang akan ditempuh dalam kegiatan ini mencakup beberapa tahap sebagai berikut:

\section{Persiapan dan Pelaksanaan kegiatan}

Tahap persiapan merupakan tahap awal sebelum pelaksanaan. Dalam tahap ini ada beberapa hal yang dilakukan adalah koordinasi internal, dilakukan oleh Ttim untuk merencanakan pelaksanaan kegiatan, lalu meninjau lokasi sekaligus menyampaikan rencana kegiatan kepada kepal SLBN Pembina Kalimantan Timur, dan menyiapkan lokasi sebagai tempat pengabdian masyarakat.

Materi yang disajikan adalah memperlihatkan benda benda di sekitar sekolah beserta pemanfaatannya sambil bernain dengan siswa SLB, bermain dalam hal ini adalah memperkenalkan benda-benda yang ada di lingkungan sekolah kepada siswa SLBN secara berulang-ulang sambil membuat teriakan berirama, menyebut bendaitu dengan memasukkan pada nyanyian, dan lai sebagainya. Hal ini dilakukan untuk agar bendabenda tersebut selalu ada di dalam ingatan siswa.

\section{Evaluasi, Refleksi, dan Penutupan kegiatan}

Wawancara dengan siswa yang telah mengikuti kegiatan dan wawancara kepada guru yang mendampingi siswa saat pelaksanaan pengabdian masyarakat. Pada akhir kegiatan peserta 
dan Tim melakukan refleksi untuk mengetahui apa saja hikmah meliputi kelebihan dan kekurangan dari hasil kegiatan yang sudah dilakukan sehingga dapat dijadikan dasar dan landasan dalam kelanjutan di kegiatan yang akan datang.

\section{Pengambilan Data}

Metode Pengambilan Data yang dilakukan pengabdi adalah dengan observasi dan wawancara langsung saat kegiatan berlangsung dan setelah kegiatan selesai dilaksanakan.

\section{Jadwal Pengabdian}

\begin{tabular}{|c|c|c|c|c|c|}
\hline NO & Jenis Kegiatan & $\begin{array}{c}\text { Januari } \\
2020\end{array}$ & $\begin{array}{c}\text { Februari } \\
2020\end{array}$ & $\begin{array}{c}\text { Maret } \\
2020\end{array}$ & $\begin{array}{c}\text { April } \\
2020\end{array}$ \\
\hline 1. & $\begin{array}{l}\text { Pembuatan proposal pengabdian } \\
\text { masyarakat }\end{array}$ & & & & \\
\hline 2. & $\begin{array}{l}\text { Melakukan survey lokasi dan } \\
\text { persiapan kegiatan }\end{array}$ & & & & \\
\hline 3 & $\begin{array}{l}\text { Pelaksanaan kegiatan pengabdian } \\
\text { masyarakat }\end{array}$ & $\stackrel{0}{\circ}$ & & & \\
\hline 4 & $\begin{array}{l}\text { Evaluasi kegiatan pengabdian } \\
\text { masyarakat }\end{array}$ & & & & \\
\hline 5 & $\begin{array}{l}\text { Pembuatan laporan hasil } \\
\text { pengabdian masyarakat }\end{array}$ & & & & \\
\hline
\end{tabular}

\section{HASIL DAN PEMBAHASAN}

Pengabdian masyrakat ini dimulai sejak akhir bulan Januari hingga bulan Februari 2020. Kegiatan pemanfaatan lingkungan sekolah ini dilaksanakan secara rutin setiap minggunya yaitu pada hari-hari tertentu disaat siswa SLBN Pembina siap menerima kami. Kegiatan ini sengaja dilaksanakan secara fleksibel karena susahnya menarik perhatian anak berkebutuhan khusus untuk menerima pelajaran. Demikianlah cara kami sehingga lingkungan sekolah mereka kami jadikan sebagai media pembelajaran untuk belajar.

Pengenalan lingkungan sekolah sebagai media pembelajaran bagi siswa SLB begitu sulit tapi menyenangkan, kondisi siswa SLB harus diberikan berulang-ulang agar dapat bisa dipahami, dengan demikian maka kami beserta tim menggunakan beberapa cara agar siswa mampu cepat menerima pelajaran. Metode yang telah kami lakukan adalah ceramah, tanya jawab dan sambil bermain.

Pertemuan ke 1, jumlah siswa yang ikut sebanyak 11 orang. Kegiatan dimulai pukul 09.00 hingga pukul 10.00, kegiatan ini kami hentikan karena sepertinya siswanya kurang semangat dan belum terlalu kenal dengan tim kami, sehingga kami mengupayakan untuk perkenlan saja dengan memberikan permen kepada mereka. Di tahap ini, kami sangat kewalahan karena tim kami belum kompak dan masih mencari-cari cara apa yang mesti harus dilakukan agar bisa membuat anak-anak ini bisa suka sama kami. Kegiatan ini dipandu oleh Disman Ubang dan Andi Alif Tunru, S.Pd., M.Pd. yang didampingi oleh Afdal, S.Pd., M.Pd selaku ketua tim, serta Novita selaku tim dokumentasi dan penyusun jadwal kegiatan.

Pertemuan ke 2, jumlah siswa yang ikut sebanyak 12 orang, kegiatan ini dilaksanakan pada pukul 09.00 sampai pukul 11.00. Siswa sudah mulai tersenyum melihat kami saat menemui mereka di sekolah, dengan modal itu maka kami bertim mengajak mereka keluar kelas yang diantar oleh guru kelasnya untuk bermain di lingkungan sekolah. Kami tidak melalukannya secara formal, namun seolah-olah tidak ada kegiatan sama sekali, kami langsung nermain bersama anak-anak dengan berjalan-jalan dan bernyanyi sambil memegang benda- 
benda di sekitarnya. Kadang kala kami duduk bertepuk tangan dan main tebak-tebakan sambil menanyakan nama benda yang kami pegang. Kegiatan sosialiasi dilaksanakan dengan metode yang berbeda dibandingkan minggu sebelumnya, hal ini bertujuan agar tidak jenuh mendengarkan apa yang kami sampaikan.

Pertemuan ke 3, jumlah siswa yang ikut sebanyak 10 orang, kegiatan ini dilaksanakan pada pukul 09.30 sampai dengan pukul 11.30. pada tahap ini, kami mengawali dengan membagikan kue kering kepada mereka sebagai bentuk rasa perhatian kami dengan mereka agar mereka mau berteman dengan kami, dengan demikian kami selaku tim pengabdi mencoba menerapkan tanya jawab kepada mereka tentang apa yang telah kami perkenalkan sebelumnya, sambil bernyanyi, melompat-lompat, bertepuk tangan, dan lain sebagainya kami lakukan agar mengingatkan daya ingat mereka apa yang telah mereka pelajari sebelumnya, ternyata dari 10 yang hadir ada 6 yang masih mengingat benda-benda yang telah diajarkan dan 4 orang anak yang lupa. Namun tetap kami coba berulang-ulang untuk mengingatkannya dengan cara menyebutkan nama benda tersebut yang dipadukan dengan nyanyian.

Pada minggu ke 4, jumlah siswa yang ikut sebanyak 12 orang, kegiatan ini dilaksanakan pada pukul 09.00 sampai 11.00. Pada pertemuan ini kami sangat beruntung karena orang tua siswa datang ke sekolah waktu itu, sehingga anak-anak pun merasa terjada dan percaya diri dengan apa yang mereka ingin lakukan. Kendala kami kebanyakan pada anak yang tunagrahita yang IQnya di bawah 50. Mereka memang susah untuk mengingat sesuatu, sedangkan temantemannya yang lain lebih cepat mengingat. Salah satu cara yang kami lakukan untuk tahap ini adalah memberi pertanyaan-pertanyaan yang berkaitan dengan fungsi, kegunaan, atau yang berkaitan dengan benda-benda di sekitarnya. Dengan antusis mereka berlomba untuk menjawab, namun masih ada juga 2 orang anak yang masih terdiam (tunagrahita dengan IQ di bawah 50), meskipun terdiam tidak menjawab namun kami sangat bersyukur karena anak-anak tersebut sudah bisa tersenyum untuk kami dan mau diajak bicara.

Pertemuan ke 4, kami pamitan pada pihak sekolah dan siswa SLB khususnya yang telah kami temani dalam kegiatan pengabdian ini,

\section{Pembahasan}

Kami rasa bahwa apa yang telah kami lakukan selaku tim sangat membuat hati kami bahagia karena mampu membuat anak-anak tersebut bisa tersenyum kepada kami, dan mampu mengajak mereka bermain bersama. Senyuman mereka adalah kebahagiaan dan keberhasilan bagi kami.

Dalam kegiatan ini terlihat banyak peningkatan, mulai dari peningkatan semangat mereka sampai saat kami akan berpisah mereka menangis agar kami tetap ada untuk menemani. Meskipun jumlah mereka yang ikut tidak terlalu banyak namun antusias orang tua dan guru yang membantu kami sangat membantu keberhasilan kegiatan kami. Anak berkebutuhan khusus tidak bisa dipaksakan, berapapun jumlahnya tidak jadi masalah, namun yang terpenting adalah sejauh mana kemampuan kita mampu untuk bisa mencuri hatinya sehingga mereka mampu dan bisa menerima kita sebagai temannya.

Berdasarkan pengamatan, tim pengabdi melihat bahwa dengan kegiatan tersebut terlihat antusias dan rasa senang siswa bisa belajar di lingkungan sekolah. Hal ini menunjukkan peran tim pengabdi yang dibantu oleh guru dan orang tua dalam pelaksanaannya. Dengan dukungan orang tua dan guru maka materi yang disampaikn melalui penggunaan lingkungan sekolah sebagai media lebih mudah untuk dipahami oleh siswa.

\section{Indikator keberhasilan kegiatan}

Beberapa indikator kegiatan yaitu, mendapatkan izin kepala Sekolah, mendapatkan fasilitas tempat kegiatan, pendampingan oleh guru dan orang tua siswa saat kegiatan 
URL:

http://www.sttibontang.ac.id/jurnal/index.php/pay

dilaksanakan, siswa yang mengikuti kegiatan terlihat antusias, dan eberlanjutan kegiatan setiap minggunya.

\section{Permasalahan Penyelesaiannya secara Adiministratif dan Teknis}

Pada kegiatan ini semua prosedur kami lakukan dengan baik yakni mendatangi Kepala SLBN Pembina Kalimantan Timur untuk meminta izin secara resmi, dan beliau sangat antusias dan mendukung kegiatan tersebut. Secara teknis kegiatan ini dilaksanakan di tempat yang sudah disediakan oleh Kepala SLBN Pembina Kalimantan Timur yang dilaksanakan setiap harinya.

Tim pelaksana

Pelaksana dalam kegiatan ini adalah kami bertiga (Afdal, S.Pd., M.Pd dan Disman Ubang, dan Andi Alif Tunru, S.Pd., M.Pd.). Dalam pelaksanaannya kami meminta bantuan guru kelas dan orang tua siswa untuk membantu kami di lapangan.

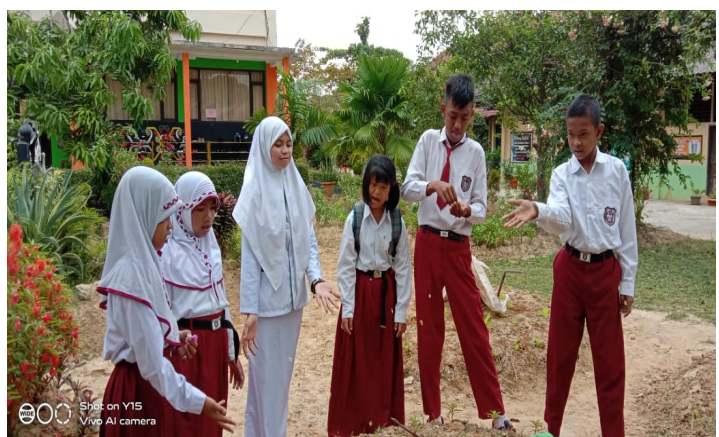

Gambar I. Foto Siswa SLB

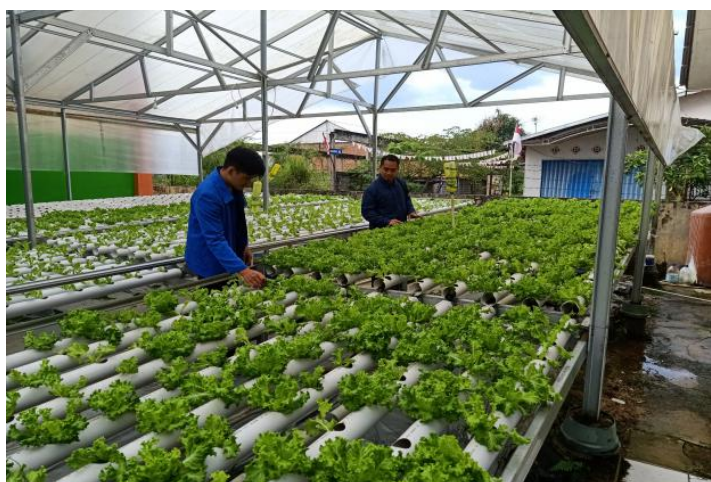

Gambar II. Hasil Pemanfaatan Lingkungan Sekolah

\section{KESIMPULAN}

Kegiatan ini sangat bermanfaat bagi siswa SLBN Pembina Kalimantan Timur, karena siswa terlihat senang dan antusiasdalam menerima pelajaran. Kegiatan ini menggunakan berbagai macam metode dalam pelaksanaannya, sehingga dapat berhasil. Metode yang digunakan adalah ceramah, Tanya jawab, bermain, dan lain-lain.

\section{Saran}

Sebaiknya kegiatan ini menjadi pertimbangan untuk revisi kurikulum SLB dalam hal KKM, untuk mencapai KKM siswa SLB tidak mesti harus 100 persen menyesuaikan denagn aturan yang ada, namun membuat siswa SLB tersenyum itu sudah berhasil, dan hendaknya kegiatan ini rutin dan berkelanjutan adar dapat memotivasi dan memicu semangat siswa dan gurunya. 


\section{Ucapan Terima Kasih}

Penulis mengucapkan terima kasih kepada Kampus Universitas Widya Gama Mahakam Samarinda yang telah memberikan dana pada kegiatan pengabdian masyarakat ini melalui LPPM, sehingga bisa terselesaikan dengan baik dan tepat waktu.

\section{DAFTAR PUSTAKA}

Mulyasa, E. (2006). Kurikulum Tingkat Satuan Pendidikan. Bandung: PT. Remaja

Rosdakarya.Hamalik, O. (2000). Psikologi Belajar Mengajar. Bandung: Sinar Baru.

Purwanto, N. (2013). Psikologi Pendidikan. Jakarta: Rosdakarya.

Walgito, B. (2004). Pengantar Psikologi Umum. Yogyakarta: ANDI Yogyakarta.

\section{Profil Penulis:}

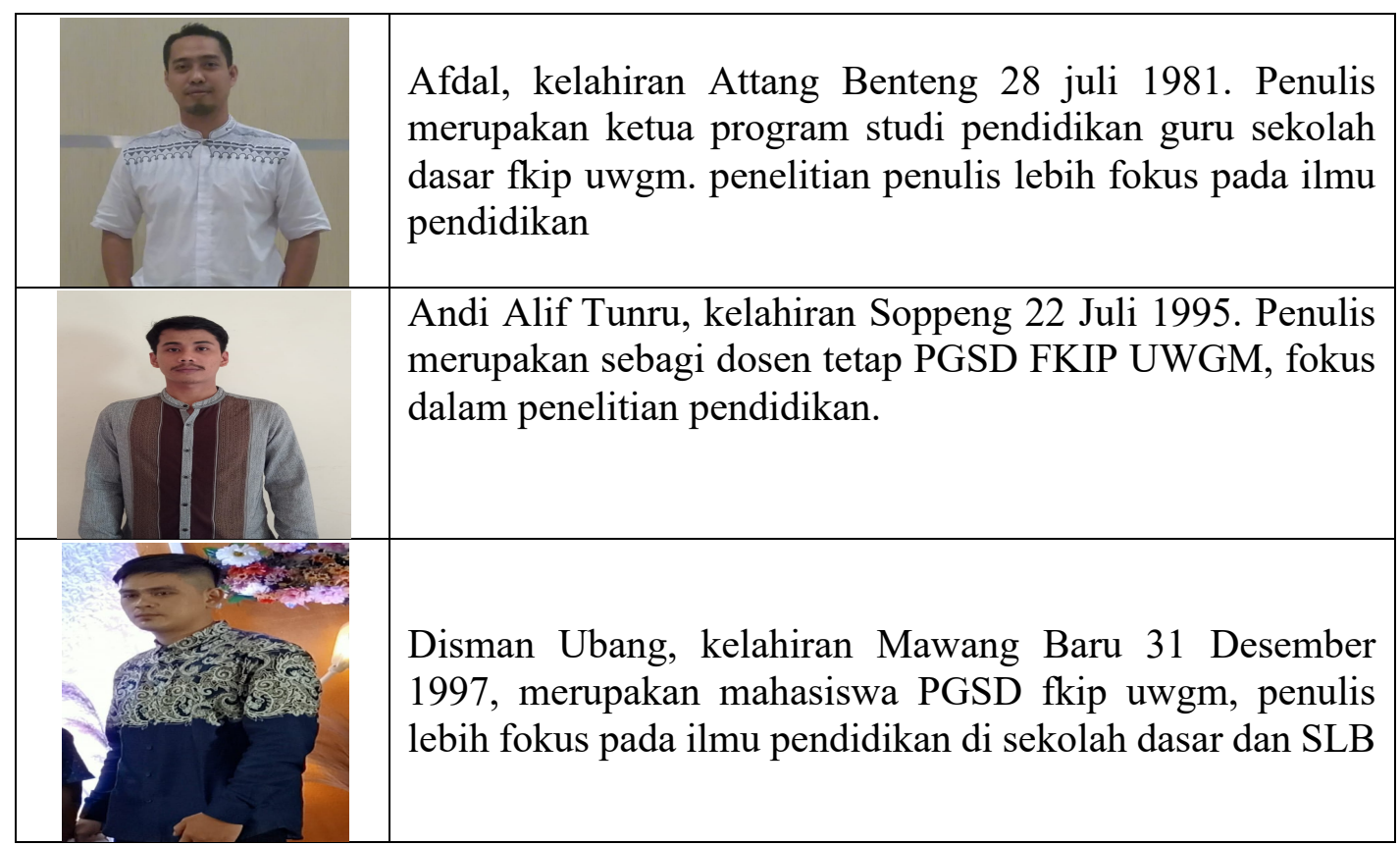

